\title{
THE NEED OF INTERDISCIPLINARY PARTNERSHIP IN RECREATION AREA TO WORK WITH STREET YOUTH
}

\author{
Dovilè Lisauskienè \\ Vilmantė Aleksienè \\ Lithuanian University of Educational Sciences, Lithuania
}

\begin{abstract}
Both Europe and Lithuania aim at involving youth into the activities, encouraging their activeness and participation in social life. The article analyzes the social work with street youth. The initiatives of social work in informal environments of a city streets by applying interactive methods, interfering with creative-artistic or sports leisure activities are discussed. The results of the research carried out highlighted the need of interdisciplinary partnership in recreation area to work with street youth.
\end{abstract}

Keywords: socio-cultural work, recreation, street art, street youth.

\section{Introduction}

There are two general objectives distinguished in the European Union youth policy: to pursue that young people are given more equal opportunities in education and the labour market and to pursue active citizenship, social inclusion and solidarity of young people (EU Youth Strategy, 2009). The strategic objective of the Lithuanian National Youth Policy Development Programme for 2011-2019 is to create a favourable environment (conditions) for young people's lives and self- expression in Lithuania.

According to the data of Eurobarometer in 2013, the youth activity is increasing every year, but only one in five $(22$ percent) participates in the activities of youth organizations, 15 percent get involved in local community activities, and 44 percent were not involved in any activity lately. Youth unemployment is very high - 8.7 million young people can not find an appropriate work, 27 million young people are prone to poverty and social exclusion (Eurostat, 2014), the same trend prevails in Lithuania as well: in the first quarter of 2016 there were 23.4 thousand young unemployed people aged 16-29, youth activity is low - only $27-28$ percent are involved in some activities, there is a widely spread stagnation of the formal education system, youth 
organizations engage only 10-13 percent of the youth (Meldžiukas, 2016). This suggests that the existing methods fail to meet the expectations.

Working with young people in an informal environment, using interactive methods interfering with their creative-artistic, sports or other leisure activities it's just part of youth work forms that highlight new trends of activities with the youth in Europe (Kellett, 2011; Dunne, et al., 2014; Georgallis \& Moyart, 2016). Innovative methods of work pose new challenges on social workers, whose one of the roles is recreational role, i. e. organizing leisure activities (Spierts, 2003).

The Lithuanian social workers carry out the function of organizing and implementing leisure activities in social institutions (Qualification requirements for social workers, 2015). The aim is to move away from traditional methods of work to non-traditional ones, with the efforts of the service reaching the customer, rather than the customer reaching the service. Such innovations as mobile youth work, youth work in open spaces and others are applied. Such methods are particularly suitable for the development of socio-cultural work ${ }^{1}$ with disadvantaged youth.

Lately in Lithuania there is a new activity of social workers - work with street youth ${ }^{2}$. The focus is on the socio-cultural environment of young people by offering them attractive forms of expression, in order to enable young people not only to realize their potential, but also to express the accumulated grievances that prevent them from integration into social activities. This is another challenge that requires expertise in the field of recreation ${ }^{3}$. There is a lack of more systematic work in this area as well as a lack of collaboration.

Arts are recognised as a particularly effective form of socialization: artistic cultural events help a person to integrate into the society, to adapt to its requirements, or on the contrary - to resist social environment and rebel (Brazauskaitė \& Dikčiūtė, 2015; Šinkūnienè \& Savickaitè, 2008). Despite that, up to now social workers as well as artists implement socio-cultural projects with the street youth separately. There are also more problems that hinder the development of socio-cultural work in Lithuania like, institutional attitude of social workers towards problem solving, lack of funding for socio-cultural activities, lack of competence of social workers for carrying out socio-cultural activities, and absence of the interinstitutional recreational model to work with youth (Dvarionas, Motiečienè, Ruškus, Mažeikienè, \& Naujanienè, 2014).

\footnotetext{
1 Sociocultural work - socialisation and empowerment of a person, group or community by applying sports, artistic and other meaningful leisure activities (Spierts, 2003, Šinkūnienè, 2013)

2 Street youth - young people aged 14-29 who spend a significant amount of their leisure time on the street without care of parents or guardians (Darbo su jaunimu gatveje praktinis gidas /Practical Guide for Work with Street Youth/, 2015)

3 Recreation -personal benefits in terms of meeting physical, emotional, philosophical, and other important health-related needs of participants. Expanding role in health, wellness, quality of life, and environment (McLean, D. D., \& Hurd, A. R., 2015)
} 
The study of Lisauskienè \& Aleksienè, (2016) highlighted the commitment of social responsibility at different levels (formal vs. informal) and different environments (educational vs. creative) the socio-cultural work carried out by street youth workers and street art professionals simultaneously. The findings of the interview revealed the need for cooperation in synergy. It turned out that professionals working with this target group are not aware of each other's activities, though both sides emphasize the need for systematic cooperation.

The aim of this study is to base the need of interdisciplinary partnership in recreation area working with street youth.

The objectives are to analyse the socio-cultural work with disadvantaged youth trends in Europe; to highlight the initiatives of work with disadvantaged youth in Lithuania; to reveal attitudes of social workers towards creating interdisciplinary partnership in recreation area working with street youth.

Qualitative research methods are 1) systematic review of European and Lithuanian publications. 2) semi-structured interview and content analysis.

\section{Review results}

\section{Socio-cultural work with disadvantaged youth trends in Europe}

We search for answers to a question: what are the models of socio-cultural work with disadvantaged youth in European countries. All European countries have different experience working with street youth. We take some examples. In almost all institutions in Germany, where Mobile Youth Work (street work) is carried out, staff members formulate working principles, which they hold on to in their work. These working principles will be presented below selectively. They also serve as the basis for the description of quality criteria for Mobile Youth Work (Specht, 2010). In spite of the defensive-waiting strategy, establishing contacts remains an interaction, which is actively organised and forced by the street worker. The street worker must be prepared for presenting himself. Every Mobile Youth Worker will have to find his own style in the Great Britain. It is important to be authentic and to be alert for non-verbal and verbal signals. This demands self-reflective behaviour towards one's own biography (Tiffany, 2010). The concept of mobile work with youth is still only partially detected in Slovakia. Considering the fact that the whole sector of work with youth is only being formed, the new ways and new starting points are sought and discovered. It was important for the concept of mobile work with youth to create the space for implementing its methodology. The methods of work are oriented towards an individual, group and partially also the community (Kulifaj, 2010). 
European consultation with street-connected children and young people for the UN Committee in the report made the following recommendations for the European countries working with street youth:

- To establish police training to defend children's rights; establish multicultural police forces; create local forces that would have a close relationship with the public in their area;

- To open a social dialog between the young people, social workers, authorities, the public;

- To recognize and determine the street as a place of creativity. Local authorities should appreciate the artistic expressions of local residents, from both a cultural (graffiti, music, sculpture, film) and sport-based point of view. For this to happen, it is important to open community centres available for everyone, where the young people can meet, even those usually marginalized. Social workers must reinvest in the street and to use it as space of creativity (Rapport of Dynamo International and Consortium for street children, 2016).

It can be stated that all European countries have different experiences of work with social risk youth on the street; however, key trends that are of importance for all the countries were identified, namely: preparation of a social worker for work on the street, finding an individual working style, ability to make a contact, and use of different working methods.

The fact that the European consultation with street-connected children and young people for the UN recommended for the European countries to recognize and determine the street as a place of creativity, demonstrates the significance of artistic recreational activities for work with youth on the street.

\section{Initiatives of work with street youth in Lithuania}

In Lithuania, the area of social work on the street is still at an early stage of development. The first projects of street social work in our country are entirely consistent with the substantive provisions of both paradigmatic posture and its methodology. That is why they can be recognised as the same phenomenon as in the West, which is known as street social work (Švedaite-Sakalauske \& Eidukevičiūte, 2015). The fact that in Lithuania so far the tradition of social work on the street has not formed yet does not mean that there is no such need. The research by Laureckis \& Petružytė (2016) revealed that help for youth on the street is necessary. Young people lack social skills, self-confidence, their self-assessment is negative, and they are prone to delinquent behaviour, selfmutilation or suicide. Young people feel rejected, are angry with themselves and the whole world. They are unwilling to engage into social activities or educational sessions; more often choose informal not binding gatherings. 
Other researches show that street youth involves into different recreational activities organised on the city streets. The Lithuanian success stories of work with street youth are the projects executed by street art professionals (Aleksienè \& Ambrazaite, 2014). The beginning of the street art was a protest, rebellion against the established rules that helped the artists to deliver their opinion and to express the accumulated anger and to attract the attention of members of the public (Shapiro, 2005). Today professional street art is a postmodernist art form, where the artistic language is a social phenomenon and meaningful form of communication.

The results of the research by Aleksienè and Ambrazaite (2014), where three famous Lithuanian street culture project operators, experts of different street art branches - street dances, DJs, music, graffiti experts took part, showed that the street art projects implemented in Lithuania as social art practice and preventive criminal behaviour practice help to distract the youth from the activities unacceptable to the society and to make positive socialisation. In the organisation and implementation of social artistic projects, interdisciplinary teams of artists and social workers work in cooperation. It indicates that art in social activities is an effective form to work with youth; however, it so far has evidenced during individual social art projects and lack support from the society and social policy-makers.

The research by Lisauskienè and Aleksiene (2016) also highlights it. The research aimed at investigating the peculiarities of recreational activity organisation in social work with the youth. The analysis of the obtained data demonstrated that the means of street art can be beneficial to a young person not only in self-realisation, being exposed to the society or entertaining others, but also an important factor of personality development. Another important fact is that street art can be a way to solve social problems, such as abuse, hooliganism, unwillingness to learn. The benefits of recreational activities are underlined in the answers regarding the changes of personality when getting involved into recreational activities. The youth becomes more self-confident, happier, feel better, are able to trust adults and show more respect when communicating with each other. The research results show the role of a social worker in recreational activities. Social worker should be an active professional in the professional field, be willing to get involved into non-formal activities with the youth and show empathy. A social worker should be able to professionally and constructively plan and validate own activities, be aware of street subculture and be able to do street work.

The results of the research by Lisauskienè and Aleksienè, (2016) disclose the demand for synergetic cooperation of street youth workers and street art professionals when working with street youth. It appears that the specialists working with the target group are not aware of each other's activities, yet they 
claim that it is important to cooperate; they also highlight the relevance of mediation implemented by a social worker. In order to elaborate social work with the social risk youth, it is important to develop recreational activity methods in social work and improve the competences of social workers to coordinate street youth leisure activities.

The analysis of this research demonstrates that a social worker working with the youth of social risk groups is exposed to new challenges demanding new working environments, new work forms and practical skills of recreational activity.

How do street youth workers deal with these challenges? Is mission "the street as a place of creativity" possible?

\section{Interview design and results:}

\section{Attitudes towards creating interdisciplinary recreation partnership to work with street youth}

In Lithuania, work with street youth is just at its early stage of development. In Vilnius city there are two functioning groups established on the initiative by young social work specialists, which independently develop this field of social work. So far, there is no regulation for such activities of street youth workers in Lithuania.

Based on the conclusions of the researches presented above, street art is an effective form to work with youth, the goal of the research is to reveal attitudes of social workers towards creating interdisciplinary partnership in recreation area for the work with street youth.

Type of research - qualitative research. The method of data collection: is a semi-structured interview. The method of analysis; qualitative content analysis. The method of sample: convenience sampling. According to V. Žydžiūnaite (2006), convenience sampling consists of variables that are easy to find taking into consideration the characteristics of informants that are of interest to the researcher.

The research sample. The informants who participated in the study were 4 social workers involved in work with street youth. So far, only such a small staff is constantly working on the street in Vilnius. In other Lithuanian cities / towns this activity is not being developed. Social workers were interviewed in a time of "Work With Youth Forum" which took place in Vilnius, 29 September, 2016. Interviews with informants each took an average of 25-30 minutes.

The method of analysis. The research data obtained during the interview is analysed by applying the qualitative content analysis method. The method was applied based on the qualitative content analysis steps provided by V. Žydžiūnaitė, G. Merkys, S. Jonušaitė (2005), which include: multiple text 
reading, distinguishing of categories based on key words, dividing of category content into subcategories, interpreting and justifying of categories and subcategories with evidence extracted from the text. Two essential categories were distinguished: challenges of integration of recreational activities and interdisciplinary partnership. In the analysis of the research data subcategories are presented in bold.

In the analysis of the results of the interview, the opinion of the research participants is presented under the following codes: first social worker (A), second social worker (B), third social worker (C), fourth social worker (D).

\section{Questions:}

1. What are challenges and / or interferences of integration of recreational activities into social work with street youth?

2. Is there a need for creating interdisciplinary partnership in recreation area for the work with street youth?

\section{Challenges and interferences of recreational activities integration}

A negative government attitude and dominating stereotypes in the society is a challenge for street youth workers. By the results of their difficult activities they have to prove both to the government representatives and the whole society that street youth can be creative, positive, they can change and be useful for the society. An important aspect is that, according to the research participants, in Lithuania all innovations are difficult to be implemented, and social area is not an exception. New working methods, new approach receive resistance. "...you talk to the government representatives and feel that you go to the wall..." (C). "..I hear so many excuses but not problem solving options..." (A). "...at first, it is necessary to know a young person and only then to offer artistic activities, as the majority has negative attitude towards them, there's just no need..." (D). “... I often hear - what that culture could change?...” (B).

Another important problem of integrating recreational activities into social work is the lack of professionalism. There is no institution that would train workers for work on the street. Initiative groups learn from their own experience, use good experience of foreign countries; however, in Lithuania they have nobody to discuss or consult with. <...it is strange when now universities invite me to deliver a public lecture on the work on the street...> (B). <...only foreign literature, forums and own contacts helped me to understand the rules for the work on the street...> $(A)$.

The main obstacle preventing the integration of recreational activities into social work area is funding. In the opinion of the research participants, the state is unable to allocate money as this type of activity is not regulated, and there are few competitions announced or the conditions for participation therein are unreal, long-term activity experience is required, great work results, etc. "... even 
there are not many socio-cultural competitions announced or the conditions for participation therein are unreal..." (A) "...if you have a good idea, sometimes you need also own funding..." (C), "... and where are leisure zones where youth could engage in artistic activities?..." (D), ".. the mere fact that there are no premises where we could normally work says it all..." (B).

The analysis of the interview showed that informants unwillingly speak about cooperation with artists and other colleagues only because this experience raises new challenges for them at work. They state that $<\ldots$ it is difficult to start communicating with other specialists as they feel lost when they see you...> (A), $<\ldots$ they see you as a rival, and maybe as an evaluator of their activities ...> $(C)$, $<\ldots o f t e n$ joint activities are seen as additional work requiring lots of efforts and time... $>(D),<\ldots$ it requires lots of time and efforts so that these relationships continued... $>(B)$.

Thus, according to the informants, it is complicated to develop the activities of social work with street youth. It requires great determination, patience and desire to help young people. The following main obstacles in the integration of recreational activities into social work were identified: unregulated activities, lack of funding, lack of professionalism and experience of work on the street. The main challenges that are faced include insufficient attention from the government representatives for this problem and stereotypes dominating in the society, fear of innovations.

\section{A Need of creating interdisciplinary partnership}

Despite complicated experience in creation of partnerships, the opinion of all the informants was unanimous that one of the most important factors in working with risk youth is social network. The results of each worker's activities depend on the relationship established by him/her with specialists of other areas. "...what help we can offer for youth depends on to what institutions we can send them ... $<\ldots$ the stronger cooperation network among organisations is, the more you can help... >” (A), “...We do not know what problems we face on the street; thus, it is important to make as many contacts as possible with other organisations of that neighbourhood" (B), <...our goal is each month to visit one new organisation... and then it is of great importance to constantly keep that relation: to call, come over" $(C)$. "...network is very important, the basis should be given by government representatives." (D).

The need for cooperation was highlighted by the understanding of research participants that artists are not social workers, and social workers are not artists. Cooperation is necessary also in order to learn from one another. "... how properly should communication with them be started?" these are the questions asked by our partners.." (C). "...for many years I have been working with youth, quickly make contact with them, but I really do not know how to paint..." (A). "...I would need more psychological knowledge as there are 
situations when young people are very sensitive, and I do not know what to say to them.., the latter is stated by our partners" (D).

The need for cooperation in creative area revealed through the answers by the research participants that street youth is different in every neighbourhood. The need for cooperation between youth workers with street art professionals depends on the willingness of youth to involve into recreational activities. $<\ldots$.. One thing is the rage. Graffiti was very popular...> (B), <...Arts, I would say, is a softer part.. and, yes.. I like some, indeed... Guys in the centre are bit different, a cultural thing...> (C). It was stressed that in order to involve youth into recreational art activities also in other neighbourhoods it is necessary to achieve a certain communication level with youth. <...I do not know, but to my mind, it is absolutely possible and very cool. Just such stage "of acting together" should be achieved and here it is very important trust with guys and you use it as a tool so that they can create something... $>$ (A).

The fact that street art is not valued as a professional art area in the society is one of the obstacles that stops youth from involvement into creative activities. <. We even saw that they painted, have bottles, but they say "no, .. I can't". somehow, as they were afraid that we will inform about them...> (D). However, the role of an artist as a teacher was stressed, with the help of which youth, and at the same time the society, would understand that street art may be professional and socially important. $<$... With the help of artists it is possible to find the forms which would make minimum harm and remained what is called, for example, graffiti. For instance, on the street to spill from sand a certain message, which in case of real wind disappears and makes no harm to anything, but graffiti was made, it is artistically, creatively thought-out measure. The same is with rap, isn't it? Just recently a rap story or Lithuania's history in rap was famous in all social media in Lithuania. In fact, it tells historical events but also says, there Germans, Polish or Russian... when Lithuania was oppressed...> $(C)^{4}$.

The analysis of the research results revealed the role of a social worker mediator. In the opinion of the informants, a social system is best understood by a social worker, thus, he should be able to form the network of different government, art, employment, healthcare specialists, keep the relationship with them, and if necessary, to find a necessary specialist for solving the young person's problem <...after all, a social worker should be known in the community, he should be an active member of the society and that everyone knew him...> (D). <...it would be great if specialists knew about each other's activities and wanted to cooperate... $>(B),<\ldots$ a social worker should gather

\footnotetext{
${ }^{4}$ The informants had in mind a popular video clip: https://www.youtube.com/watch?v=V4veBuE_QA0
} 
together not only other social workers but also specialists of different areas, after all, he is entitled the role of the enabler...> $(A)$.

Hence, cooperation with specialists of other areas and having as many contacts as possible create possibilities for helping the young person and grant more confidence to the social worker himself. Thus, interdisciplinary partnership would grant more stability to the activities, help managing unexpected situations, develop competences of workers, and improve operational skills.

\section{Conclusions}

1. Both in European countries and in Lithuania work with social risk youth on the street is under development; however, every country has different work results and experience. Recommendations "European consultation with street-connected children and young people for the United Nations" provide general guidelines for the countries towards what social work on the street should be oriented: creation of a social dialogue between youth, social worker and society; greater involvement of police and other law enforcement authorities in protecting child's rights; understanding street as a creative space.

2. In Lithuania street youth workers only start their activities, thus, youth workers face new challenges, innovative working methods and practical skills of recreational activities are to be developed. Specialists (social worker and street art professional), working with this target group do not know about each other's activities, but they state that it is important to cooperate and cooperation that could be implemented by a social worker in order to foster social work with social risk youth is of relevance.

3. The main challenges faced by specialists working with street youth include insufficient attention from the government representatives, negative stereotypes dominating in the society, fear of innovations; key obstacles for integration of recreational activities into social work are the following: unregulated activities of social work on the street, lack of funding, lack of professionalism and experience as well as avoidance of work requiring additional efforts.

4. In view of social workers, interdisciplinary partnership in creating spaces attractive to street youth and carrying out creative activities is necessary. Cooperation would provide more stability, help to control unexpected situations, develop workers' competences. The main obstacles for the development of this cooperation are as follows: stereotypes dominating in the society and the government that street art is not a professional area of 
art. Youth is not motivated to engage into the activities as they think that this type of activities is illegal and those who want to create, do it in secret.

\section{References}

Aleksienè, V., \& Ambrazaitè, R. (2014). Jaunimo kultūrų įvairovè: gatvès meno projektai kaip nusikalstamo elgesio prevencija [Youth Cultural Diversity: Street Art Projects as Prevention of Delinquent Behavior]. Socialinis ugdymas, 2, 68-82. doi: http://dx.doi.org/10.15823/su.2014.06

Being young in Europe today (2014). Eurostat statistics explained. Retrieved from http://ec.europa.eu/eurostat/statisticsexplained/index.php/Being_young_in_Europe_toda $\mathrm{y}$

Brazauskaitè, A., \& Dikčiūtè, S. (2015). Meniniai-socialiniai performansai: Lietuva: VšI Menų terapijos centras.

Children in Street Situation Raise their voice. (2016). Rapport of Dynamo International and Cosortium for street children. Retrieved from http://streetchildren.org/our-work/cscpublications/

Dunne, A., Uličný, D., Murphy, I., \& Golubev, M. (2014). Working With Young People: the Value of Youth Work in the European Union. European Commission. Retrieved from http://ec.europa.eu/assets/eac/youth/library/study/youth-work-report_en.pdf

European Youth Participation in Democratic Life (2013). Eurobarometer statistics Retrieved from http://ec.europa.eu/assets/eac/youth/library/reports/flash375_en.pdf

European Union youth policy (2009). Retrieved from http://ec.europa.eu/youth/policy/youthstrategy_en

Georgallis, M., \& Moyart, Cl. (2016). Social Inclusion and Youth People. Excluding Youth: (A Threat to Our Future). Retrieved from http://www.youthforum.org/assets/2016/05/ Excluding-youth-a-threat-to-our-future.pdf

Kellett, M. (2011). Engaging Children and Young People. Centre for Children and Young People Background Briefing Series, no. 3. Lismore: Centre for Children and Young People, Southern Cross University.

Kulifaj, P. (2010). Mobile youth work in Slovakia. Mobile youth work in the global context. Documentation of the 9th International ISMO Symposium Stuttgart, 10. 77-81.

Laureckis, K., \&, Petružytė, D. (2016). Jaunų žmonių, leidžiančių laiką gatvèje, savivoka [Self-Concept of Young People who Spend Time on Streets]. STEPP: socialine teorija, empirija, politika ir praktika. 12, 7-20.

Lietuvos Respublikos socialinès apsaugos ir darbo ministro ịsakymas, $2015 \mathrm{~m}$. balandžio 21 d. Nr. A1-75 Dèl Socialiniu darbuotoju ir socialiniu darbuotoju padejeju kvalifikaciniu reikalavimu [Qualification requirements for social workers]. Retrieved from https://www.e-tar.lt/portal/lt/legalAct/TAR.73078569BC8A

Lietuvos Respublikos socialinès apsaugos ir darbo ministro įsakymas $2013 \mathrm{~m}$. gruodžio $4 \mathrm{~d}$. Nr. A1-661 Dèl nacionalinès jaunimo politikos 2011-2019 metu plètros programos [Lithuanian national youth policy development programme for 2011-2019]. Retrieved from https://e-tar.lt/acc/legalAct.html?documentId=TAR.10A2087E3527\&lang=lt

Lisauskienè, D., \& Aleksienè, V. (2016). Socialinis darbuotojas kaip rekreacinès veiklos organizatorius dirbantis su gatvèje laiką leidžiančiais jaunais žmonėmis [Social worker as a recreational activity organizer working with street youth]. Visuomenes sveikata 2016/Priedas 2, 83-91. 
Meldžiukas, J. (2016). Darbo su jaunimu paslaugos „,Kodèl tai svarbu?“ Jaunimo forumas Konferencijos pranešimų medžiaga. Jaunimo reikalų departamento prie SADM direktoriaus pavaduotojas.

Shapiro, P. (2005). The Rough Guide to Hip-Hop. Italy: Lego Print S.p.A.

Specht, W. (2010). Mobile Youth Work with a global perspective. Mobile youth work in the global context. Documentation of the 9th International ISMO Symposium Stuttgart, 10, 56-65.

Spierts, M. (2003). Balansavimas ir aktyvinimas: Metodiškai organizuotas sociokultūrinis darbas. Vilnius: VU.

Šinkūnienè, J. R. (2012) Bendruomeniškumas, komunikacija ir muzika: sociokultūriniai negalios aspektai: Monografija. Vilnius: Mykolo Romerio universitetas

Šinkūnienè, J., \& R., Savickaitè, D. (2008). Sociokultūrinio darbo dilema [Dilemma of SocioCultural Work]. Socialinis darbas, 7 (1), 108-117.

Švedaitè-Sakalauskè, B., \& Eidukevičiūtè, D. (2015). Socialinis darbas su jaunimu - pirmoji patirtis Lietuvoje [Street Social Work With Youth -the First Experiences in Lithuania]. STEPP: socialine teorija, empirija, politika ir praktika, 11, 37-53.

Tiffany, G. (2010). Detached Youth Work in the United Kingdom. Mobile youth work in the global context. Documentation of the 9th International ISMO Symposium Stuttgart, 10, 66-73. 